\title{
American Journal of Educational Research and Reviews
}

(AJERR)

\section{REGULATION OF LEARNING AND RESULTS OF BACCALAUREAT IN SCIENCE: CASE STUDY OF REGION OF MAYO - KEBBI EAST (CHAD)}

\author{
NDIGMBAYEL Reoular Urbain, Ph. D \\ Ecole Normale Supérieure de Bongor
}

\begin{abstract}
The educational action of the teacher plays a central role in the school success of students. In fact educational organisation of teaching sequencies influences greatly on the rates success of students (learners) particularly in certified Exams. It is the case of baccalaureat [A level certification) exam (Baccalaureat: Secondary school examination qualifying for entry to university, High school diploma), Bac. A (Arts based) Bac. C, D (science based)] in science in the secondary school of Mayo -Kebbi East where the rate of global success is too low $(8,40 \%$ in 2014).

This study has the interest in the impact of implementation of educational pratices of teachers in the situation of the classes for the success in Baccalaureat of the students in science senior secondary school (Terminal, Serie C, D).

It is structures in three parts as follow: the introduction that states the main question, the methodology that describes the adopted approaches to realize the study, the results from collected data in the field the discussion that confrontes the collected data in the beginning and lastly the conclusion that makes the assessment evaluation of this study.
\end{abstract}

Key Words: Regulation, teacher, Baccalaureat C and D, success, Mayo-Kebbi East.
*Correspondence to Author: NDIGMBAYEL Reoular Urbain, Ecole Normale Supérieure de Bongor 00(235) 66.21.24.15; 00(235) 99.27.32.05 reoular2000 @yahoo.fr reoular2000@gmail.com

How to cite this article:

NDIGMBAYEL Reoular Urbain. REGULATION OF LEARNING AND RESULTS OF BACCALAUREAT IN SCIENCE: CASE STUDY OF REGION OF MAYO - KEBBI EAST (CHAD). American Journal of Educational Research and Reviews, 2016,1(2): 0001-0011.

\section{eSciencePublisher}

eSciPub LLC, Houston, TX USA. Website: http://escipub.com/ 


\section{Introduction}

Chad participated to different meetings in Africa and in the world concerning education such as : Addis Abeba in 1961, Abidjan in 1964 in the international meeting in Jomptien from the 5 th to 9 th March 1990, to the Mondial Forum on Education in Dakar on Avril 2000, also in the summit of Bamako in 2000.

It came out of these meetings some recommendations particularly on the quality of education in school by instance on the fairness of the process teaching learning and on the training of teachers.

To put into practice these recommendations Chad has set at work the National Strategy of education and that of training in relation with employment (EFE in French Stratégie Nationale d'Education et de formation en liaison avec l'Emploi). This strategy has two aims : the qualitative objective that concerns the improvement of Chadian educational system by the provision of existant structures of training; other quantitative objective concerns an expansion of school and university attendencies which assure in permanent ajustment of the growth of attendance (number) according to demographic, economic and socio-cultural realities of the country.

The role of the education in the realization of these objectives of educational system is located upstream and downstream.

Upstream, measures of adjustment should be taken according to gaps observed between the results of learning and expected results. From this Strategy are born the Action Program of Education and Training ( PAEF in French) for the period of 2000-2004 which the objective to assure the promotion of human resources by the training and education, the Program of Support to the Reform of Education Sector in Chad 'PARSET) that covered the period of 2002-2015.

In spite of international recommendations ratified by Chad, elabored strategies for obtaining the objectives of education for all and the diverse actions pertinent set at work to succeed those strategies it has been noticed that the results of baccalaureat in Chad and particularly the Baccalaureat in Science are mediocre.

These are the results of Baccalaureat in Science from 2010-2014 in the Region of Mayo-Kebbi East

In 2010, over 1258 candidates registred to Baccalaureat in Science $C$ and D, 321 succeeded for $25,51 \%$. We observe that 113 candidates succeeded $(27,43 \%)$ in serie C and 290 over 1145 $(25,32 \%)$ for serie $D$.

The candidates in Serie D are ten times in number than those in Serie C.

However, the percentage of admission in Serie C $(27,43 \%)$ in higher than in Serie D $(25,32 \%)$. This low percentage in Serie D is due to higher number of students in classes. In Serie C, the number is reduced. The Terminal classes are composed in majority of students in difficulties of learning which give low results.

In 2011, over 2681 candidates in Baccalaureat 121 succeeded $(4,51 \%)$. The Serie C came first with 15 admissions over 101 for $14,85 \%$ followed by Serie D with 106 admissions over 2580 for 04 , $10 \%$. The global rate of success is $04,21 \%$.

The lower rate is seen in Serie D with $04,10 \%$ of admission. It has to be said that the high number of students in class is a negative impact.

Also, the advantage of Serie $C$ is that the ambitions students in Science classes cannot deviate in Arts, so they have no other option than to go for Serie D (Science based).

In 2012, it has been observed that the result were better than those of 2011. However these percentage of admission is lower than what was expected. We have to note that a particularly is seen in Terminal D. The percentage of admission in Serie D $(25,06 \%)$ is higher than that of Serie $C(17,23 \%)$ even though the number in attendance of students in Serie $D$ is higher than in Serie C. Which is 1225 strictly higher than 110 . From these results in Serie D and $C$ two reports are observed: both students and teachers in Serie $D$ have worked better than in Serie $C$ or the papers in Serie D is easier than in Serie C.

In 2013, the report was bitter when we look at the result in the table: the result are not better than those of 2010 and 2011.

The failure is observe in Serie D and Arts but in Serie $\mathrm{C}$, we observe an improvement the rate of 
success in Serie D (04\%) has brought an interrogation. This is imputable to the higher number of students in classes and the lack of seriousness in the work both teachers and students.

In 2014, we observed a littled improvement of capacity in Serie D $(07,60 \%)$ an net improvement in Serie C $(36,84 \%)$. From this table, it has to be noted that the rate of admission has ever reached $50 \%$. The lower rate is around $4 \%$ in Serie $D$. This report has brought two fundamental questions as follows: the teacher has he taught well his subject? The learner has he assimilated his lessons? To these two questions, this is the answer of Jone and al. (987:50): "It is important to give students awys to come back on previous knowledge and make a link to the new ones, to check their previous predictions or to preview what next. "Choose pertinent ideas, to compare the new ideas to previous ones and to manage their learning in such a way to understand the new information"

This present study has the interest of effects on educational actions of teachers in the process of learning and acquisition of knowledge of students in general and in the classes of Terminal $C$ and $D$ in particularly.

It attaches to show the influence of the regulation of learning on the results of Baccalaureat in Science in the Region of Mayo-Kebbi East.

Our choice of Secondary School of this region is justified of the fact that is one of the more educated regions in the country, but also the rate of failure of Baccalaureat is too high for illustration in 2012 the region of Mayo-Kebbi East has 76031 students over 999237 students a total number. The region came third behind the city of N'djaména (114 330 students) and the region of Logone Occiendtal (90 612 students). In the middle school the students were 39735 over 375661 students. It occupied third position behind the city of N'djaména (76 429 students) and the region of Mayo-Kebbi West (47 279 students).

In the secondary section, it takes second position behind the city of N'djaména (49 083 students) with 13974 students over 142034 for all series with 10\% (MEN, 2012).

This paradoxal situation: high number of stu- dents and low rate of success in exams has brought the authorities of the region in charge of education during workshops about the educational organization of teaching sequencies in the secondary school of the region.

Among the main questions that kept the attention of the partners of the educational system (students, parents, teachers, school authorities and politics) the question of regulation in learning and the appropriation of knowledge by students was recursive.

This study has the objective to check if there is a correlation between the regulation in learning and results of Baccalaureat in Science, in other term, we asked ourselves if the regulation in learning determines the results of Baccalaureat in Science. This study is composed of five parts as follows: Introduction, the methodology used to realize it, the results obtained, the discussion of those results and lastly the conclusion.

\section{METHODOLOGY}

The present study is explored. In the different sections of this study, two qualitative and quantitative approaches were applied. In order, to collected data form student in college Jacques Moudeina of Bongor, modern college of Bongor, college of Fianga, college of Gounou-Gaya, college of Pont-Carol and college of Guelendeng, quantitative method was used and the collected data of teachers, qualitative method was used. Findings of qualitative section were obtained from interviews with authority and parents of students in addition to responding to research questions.

\section{Data analysis}

To analyze the data collected from interview, various methods were used.

To analyze the quantitative data, descriptive and inferential statistics are used. In descriptive level, mean and frequency were calculed. In the inferential level,

\section{RESULTS AND DISCUSSION}

In this section, findings of the study are represented. Twelve questions were answered using quantitative data. 
Our sample is composed of 23 girls and 83 boys. The boys are more than girls in the classes of Terminal in Science. The situation of reduced number of girls in science is general in Africa. In fact BOUYO, A. (1993) in the report he realized for UNESCO, mentioned that the low rate of participation of girls in science studies is situated upstream and downstream.

Upstream, the teaching of science is mostly done by men, this situation can constitute a factor of hindrance, as we can see that, only few women teach science and technology the conclusion can be seen by the girls (learners) that sciences fields are only for male.

It came out from this table that over 106 answers, 99 are from series $D(93,4 \%)$ and 07 of serie $C$ $(6,6 \%)$. These results show that more of students are in science based $D$ than serie $C$. The high number of students in serie $D$ is justified by the fact that this section is in junction between Arts and science (Arts: serie $A$ and Science: série $C$, $D)$. The average students, those that have good marks in Arts in previous classes (1 1 re $L$ and 1 ère $S)$ are mostly oriented to Terminal $D$.

They are both Arts and Science students. In Chad in 2005-2006, we counted 125 divisions in serie $D$ for 24 in serie $C$ for the whole country with 10078 for 8800 boys and 1278 girls for serie D and 730 students for 696 boys and 34 girls for serie C. In the region of Mayo-Kebbi East we find out for the same period 9 divisions in serie $D$ for 3 in serie $C$ and 940 students with 869 boys and 71 girls for 52 in serie $C$ with 50 boys and 02 girls.

\section{Checking of previous knowledge of students}

To this question 58 students said that teachers "sometimes" check their previous knowledge against, 25 that said teachers " Always" check their previous knowledge and lastly 23 other confirm that teachers "Never" check previous knowledge.

From these results we can said that the majority of teachers are not checking the previous knowledge of their students at the beginning of the school year. This is inevitably followed by the failure at the end of school year because the diagnostic has not been done at the beginning to accompagny the students.
This is necessary because in the teaching-learning process it allows the teacher to know the representation of students about the question to notice the false ideas that these ones have about a topic, and to recognize the learning of students. We can say that trained teachers and sometimes those that have experience in teaching always start their courses by checking previous knowledge of students $(23,6 \%)$.

Previous knowledge constitute what the student knows in reality about a topic. The working of the data in the process of course progression is essential because it is the process that the teacher acquires the values, and attitudes, the advantages, capacities and knowledge brief the culture that is going on the teaching environment (NDIGMBAYEL, R. 2014).

\section{Awakening of the curiosity o students}

After checking of previous knowledge, 52 students said that their teachers "sometimes" awake their curiosity, 28 other confirm that their teachers "Never" do, and lastly 26 other recognize that their teachers "Always" do.

From these results, we are right to say that the rate of teachers that do awake the curiosity of their students and the rate o teachers that "Never" awake the curiosity of their students are equal. Looking at these results, we can confirme that awakening of the curiosity of students is not evident in the schools.

Moreover, it is effectively the curiosity awakening of student that allows him to like his learning and then improve his sense of research as said earlier by Cecile Delannoy.

\section{Interactions throughout the teaching of the lesson}

63 students said that teachers encourage " Always" interaction during class period against, 28 that said they do it "Sometimes" and 15 confirm that teachers "Never" do.

Here, the majority of teachers use the method of interaction. In fact the learner is the first actor of his learning by consequence he has to be fully implicated in the process of his learning. The interaction between teacher and his students has effects. For Bressoux the volume of interaction between teacher-students produce effects on 
NDIGMBAYEL, AJERR, 2016; Vol. 1(2): 0001-0011

Table 1: Result of Baccalaureat in Science from 2010-2014 in the Region of Mayo-Kebbi East

\begin{tabular}{|c|c|c|c|c|c|c|c|c|c|c|}
\hline & \multicolumn{2}{|c|}{2010} & \multicolumn{2}{|c|}{2011} & \multicolumn{2}{|c|}{2012} & \multicolumn{2}{|c|}{2013} & \multicolumn{2}{|c|}{2014} \\
\hline C & $\begin{array}{l}\text { Regis } \\
\text { tration } \\
113\end{array}$ & $\begin{array}{l}\text { Admis- } \\
\text { sion } \\
31\end{array}$ & $\begin{array}{l}\text { Regis- } \\
\text { tration } \\
101\end{array}$ & $\begin{array}{l}\text { Admis- } \\
\text { sion } \\
15\end{array}$ & $\begin{array}{l}\text { Regis- } \\
\text { tration } \\
110\end{array}$ & $\begin{array}{l}\text { Admis- } \\
\text { sion } \\
19 \\
\end{array}$ & $\begin{array}{l}\text { Regis- } \\
\text { tration } \\
58\end{array}$ & $\begin{array}{l}\text { Admis- } \\
\text { sion } \\
10\end{array}$ & $\begin{array}{l}\text { Regis } \\
\text { tration } \\
57\end{array}$ & $\begin{array}{l}\text { Admis - } \\
\text { sion } \\
21\end{array}$ \\
\hline$D$ & 1145 & 290 & 2580 & 106 & 1225 & 307 & 2315 & 109 & 1814 & 138 \\
\hline Total & 1258 & 321 & 2681 & 121 & 1335 & 326 & 2373 & 121 & 1871 & 159 \\
\hline
\end{tabular}

Table 2: Distribution of inquiries according to sex

\begin{tabular}{|l|l|l|}
\hline Sex & Number & Percentage \\
\hline Male & 83 & 78,3 \\
\hline Female & 23 & 21,7 \\
\hline Total & 106 & 100,0 \\
\hline
\end{tabular}

Table 3: Distribution of inquiries according to sections (series)

\begin{tabular}{|l|l|l|}
\hline Scientific sections & Fréquency & Percentage \\
\hline D & 99 & 93,4 \\
\hline C & 07 & 6,6 \\
\hline Total & 106 & 100,0 \\
\hline
\end{tabular}

Table 4: Checking of previous knowledge of students

\begin{tabular}{|l|l|l|}
\hline Modalities & Number & Percent \\
\hline Always & 25 & 23,6 \\
\hline sometimes & 58 & 54,7 \\
\hline Never & 23 & 21.7 \\
\hline Total & 106 & 100,0 \\
\hline
\end{tabular}

Table 5: Awakening of the curiosity o students

\begin{tabular}{|l|l|l|}
\hline Modalities & Number & Percent \\
\hline Always & 26 & 24.5 \\
\hline sometimes & 52 & 49.1 \\
\hline Never & 28 & 26 \\
\hline Total & 106 & 100,0 \\
\hline
\end{tabular}

Table 6: Interactions throughout the teaching of the lesson

\begin{tabular}{|l|l|l|}
\hline Modalities & Number & Percent \\
\hline Always & 63 & 59 \\
\hline sometimes & 28 & 26.4 \\
\hline Never & 15 & 14.2 \\
\hline Notal & 106 & 100,0 \\
\hline
\end{tabular}

Table 7: Grouping of students or assignment.

\begin{tabular}{|l|l|l|}
\hline Modalities & fréquence & Percent \\
\hline Always & 39 & 36.8 \\
\hline sometimes & 59 & 55.7 \\
\hline Never & 8 & 75 \\
\hline Total & 106 & 100,0 \\
\hline
\end{tabular}


the acquisition in Mathematics.

Sarrazy (2001) and has gone far saying that " the interaction has the initiative of teachers are not without cognitive effects on students. These effects are manifested with good students of institutionalist and assigned classes.

\section{Grouping of students for assignment.}

Concerning the group work, 59 students recognize that teachers encourage "Sometimes" the work in group against 49 that said teachers 'Always" do and 8 other have said that teachers "Never" do.

We can say that majority of teachers (92\%) encourage Students to be in group for assignment. In fact the work in groups allows to students, according to Kaye and Rogers (1975) to more from magisterial teaching to an experimental teaching by giving to each one " the satisfaction and the proud (...) of useful creation and tangible" (1975 : 34) that allows "students to learn from their mistakes and it makes that they discover by themselves (1975:36); that allows "students to work according to their own speed" (1975:84) and specially to "feel concern by the information, the knowledge and the ideas that they manipulate" (1975:67).

Following their investigation, the argue that "the efficacity and the ambition of work in group over flow the stage of learning in school program is to be set on the plan of training in human social, that constitute an essential aspect of responsibility in education of the school" (1975:77). The work in group comes to resolve the lack of teacher, his incapacity to introduce the individual activity for technical reason and constitute for the student a kind of effective help for learning. The group appears as accelerator of process for learning : the making of some difficult objects by the student himself can be seen as time consuming but this is the necessity of a group. The group allows social learning. Beyond facilitating the training, the activities in group allows to develop the trust in the student. Everyone has been confronted to obstacles, we are " all in the same boat" and everybody has a role to play for improvement. The efficient teachers supervise frequently the learning of students in formal or informal way (Buttler, 1987). They exercise a continual supervision of the work in group (Wang and al., 1990) and oc- cupy to ajust the debit of the lesson according to the need of students.

\section{Giving time to students to speak}

49 students declare that teachers "Sometimes" allow them enough time to speak during class period against 45 that said teachers don't "Always" give them time to speak and 12 other said that teachers "Never" give them time to speak.

From these results we can conclude that most of teachers give enough time to students to speak freely during their teaching period. The student learns and keeps better by expressing himself, and the class that students speak is more life full. This exercise allows us to keep the cognitive mechanisms set a work to learn from one side and in other side the mental representation of these on the topic of learning. These (mechanisms and operations) determine the quality of the work done by the students during exams either failure or success.

\section{The allowed by teachers to students for the demonstration of activities}

On the topic of demonstration in class, 44 answers said that teachers "All ways" allow them to demonstrate the given activities, 43 said that teachers "Sometimes" do against 19 other that teachers "Never" allow them time for demonstrations. We observe that teachers that give time for demonstration, are more, and that the results of baccalaureate in science will be otherwise if not better.

Now the demonstration for the concerns that the exercises answered on the board in the class according to inquiries. It is necessary to remind here the correction, of exercises are only the verification of answers already kept, otherwise the previous knowledge is transformed in teaching know ledge that the students can check.

The lack of reinforcement can bring the absence of motivation, because the student does not feel himself valued, encouraged in his efforts and he loses gradually trust in himself.

That is what happened when student fail repeatly in official exams such a BEF or Baccalaureate for years. The observations of the teaching situation reveal then that what seems to be making sense is not evident to be put in application. 
We then realize that some teachers( $15,1 \%)$ the reinforcement is not necessary. They are in fact sometimes absorbed by the content of their teaching that they do not realize that they only encourage the students less ( the students that answer quickly and correctly). We understand then easily that students are not motivated and interested by the activities they have been given they can not invest correctly in the learning of the language and may even find themselves in difficulty.

\section{Generalization of students good answers}

We have asked students if teachers generalize their good answers, 63 said that their teachers do it "sometimes" 33 other recognize that they do it "Always" against 10 other that said teachers " Never " generalize their good answers.

From these results, it is shown again a situation of uncertainty with the high rate of teachers that generalize sometimes the good answers of their student. But unfortunately the rate relatively low of teachers that "Never "generalize the good answers of students can bring hope that it can be given an important good answers of students. The generalization of good answers present several advantages (assets) the student that his good answer is generalize. Will have self esteem because what makes growth is not only what we do but what also other said...

\section{Orders for supplementary work to students in difficulties}

The results of the question on complementary work that teachers give to the student in difficulties show this: 39 declare that teachers "Never " care to working students only, 39 other $(36,8 \%)$ said that teachers care "sometimes" to working students , 28 other again

$(26,4 \%)$ said that teachers care "always" to working students.

From these results the last two answers have the same percentages that signify only few teachers work the entire class. In the contrary the majority teachers work always with working students.

This way of teaching with only the working students of the class is excluding once again the diagnostic of previous knowledge in that case students in difficulties can not fill their lack and yet students in difficulties are more.

\section{Success in assignment or given test}

Concerning the question of success in assignment or tests given in class, 56 answers confirm that they "Always "succeed against 9 other that " Never "succeed. From these results we can say that all is good for the best; rate of students that succeed sometimes in their assignments or tests give them the desire to learn enough the more we learn, more we discover, the more we have the taste of getting more. Added to this rate, the high rate of students that always succeed to assignments or given tests.

These students are flattered by the results of their work and then they are more motivated for success.

However we can deplore the situation of the minority students that never succeed in their assignments or given tests what leads them to discouragement, sometimes end up to abandoning school. In fact, this last set of students in difficulties should preoccupied teachers that should diagnosticate their previous knowledge for remedy. This remedy is nothing other than supplementary activities minutiously choose and consigned.

\section{Marking of mistakes of students in difficulties}

51 students help us to know that teachers have "Never " notified the mistakes of students in difficulties 45 said that teachers "sometimes " do it and 10 other confirm that teacher " always "do. Looking at the high percentage of teachers that never take note of the mistakes of students comparing to teachers that effectively take note we can confirm without doubt the lack of diagnostic of previous knowledge of student .

By consequence, the lacks of students preoccupy less teachers.

Generally, the majority of teachers $(48,1 \%)$ never take note of their students mistakes.

Or " education " should be view at the detection of mistakes from their sources the illusions and blindness... and this by taking note regularly in our note book the mistakes of students in difficulty that the good teacher should come to these ones and for the need to make teachers work for improvement. This shows that the majority of teachers do not check their students in their 
Table 8: Giving time to students to speak

\begin{tabular}{|l|l|l|}
\hline Modalities & Number & Percent \\
\hline Always & 45 & 42,5 \\
\hline sometimes & 49 & 46,2 \\
\hline Never & 12 & 11,3 \\
\hline Total & 106 & 100,0 \\
\hline
\end{tabular}

Table 9: Time allowed by teachers to students for the demonstration of activities

\begin{tabular}{|l|l|l|}
\hline Modalities & Number & Percent \\
\hline Always & 44 & 41,5 \\
\hline sometimes & 43 & 40,6 \\
\hline Never & 19 & 17,9 \\
\hline Total & 106 & 100,0 \\
\hline
\end{tabular}

Table 10: generalization of students good answers

\begin{tabular}{|l|l|l|}
\hline Modalities & Number & Percent \\
\hline Always & 33 & 31,2 \\
\hline sometimes & 63 & 59,4 \\
\hline Never & 10 & 9,4 \\
\hline Total & 106 & 100,0 \\
\hline
\end{tabular}

Table 11: Orders for supplementary work to students in difficulties

\begin{tabular}{|l|l|l|}
\hline Modalities & frequency & Percentage \\
\hline Always & 28 & 26,4 \\
\hline somemetimes & 39 & 36,8 \\
\hline Never & 39 & 36,8 \\
\hline Total & 106 & 100,0 \\
\hline
\end{tabular}

Table 12: success in assignment or given test

\begin{tabular}{|l|l|l|}
\hline Modalities & frequency & Percentage \\
\hline Always & 41 & 38,7 \\
\hline sometimes & 56 & 52,8 \\
\hline Never & 9 & 8,5 \\
\hline Total & 106 & 100,0 \\
\hline
\end{tabular}

Table 13: marking of mistakes of students in difficulties

\begin{tabular}{|l|l|l|}
\hline Modalities & Number & Percentage \\
\hline Always & 10 & 9.4 \\
\hline sometimes & 45 & 42.5 \\
\hline Never & 51 & 48.1 \\
\hline Total & 106 & 100,0 \\
\hline
\end{tabular}

\section{Table 14: informing parents of their children difficulties}

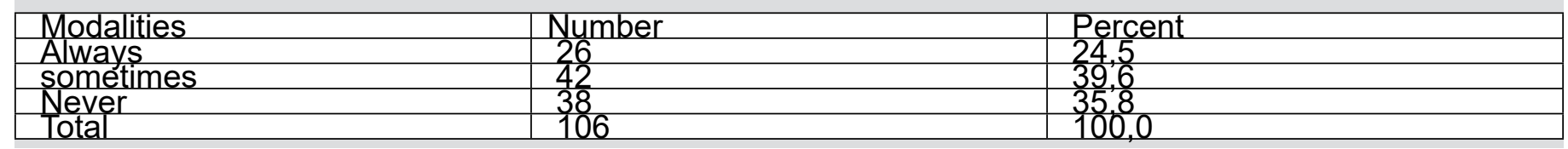

\section{Table 15: success in internal Baccalaureat}

\begin{tabular}{|l|l|l|}
\hline Modalities & frequency & Percentage \\
\hline Always & 43 & 40,6 \\
\hline sometimes & 50 & 47,2 \\
\hline Never & 13 & 12,3 \\
\hline Total & 106 & 100,0 \\
\hline
\end{tabular}


study because the follow up in school requires that we should know the strength and weakness of the learner and give them help "Error is not only the effect of ignorance of certitude, of hazard that we believe in the empire theories or behaviorists of learning, but the effect of an interior knowledge that has its advantage, its success but is now, reveal wrong, or simply inadequate. The errors of this type are not erratic or unprevisible, they made acquire knowledge "Brousseau (1983: 171).

Only a small part of teachers $(9,4 \%)$ do it because they take note of the mistakes of their students. This work allows us "to check the understanding of students is an important step of educational approach. Its permits to the teacher to check the understanding level and assimilation of it by the students, it determines the remaining of activities to come: applied exercises, tests and exams. (NDIGMBAYEL, R, 2014).

If we combine the modalities "Always" and "sometimes" we notice that the half $(51,8 \%)$ take note of the mistakes. On the other hand the half of teachers never take note of students mistakes.

For these, teachers, if the students do not understand, it is their fault because they have lack since their previous classes. We can not remedy this lack ( gap ).

From these results in the board, we can say that the failure of students in Baccalaureate is surprising. Part of teachers consider as normal that some students make mistakes and by consequence do not make effort to help them to improve.

\section{Informing parents of their children difficulties}

38 students said that teachers have never told their parents the difficulties they face, while 42 others recognize that teachers do it "sometimes" against 26 others that said teachers "Always" d. It, them came out of these results that most of teachers have any contacts with the students parents what does not help the students and those in difficulties of learning. Parents and teachers should be in permanent contact to resolve the problem of lack of level of the students. Teachers and parents have an objective: the success of each child. For this, the success of the students depends mostly of the communica- tion between teachers and parents.

The communication between teachers and parents has for objective a mutual information, the research of exchange and a good understanding based on respect and trust. By combining the modalities "Always" and "sometimes" we can say that more than the half of teachers informs parents about the difficulties of their children.

In fact, teacher and parent both look for solution and ways that can help the student in his need for success. The parent informs the teacher the positive and negative improvements seen in his child with the school and his affective behavior, and the teacher also do the some.

\section{Success in internal Baccalaureat}

To this question 50 answers declare that they have succeeded "sometimes" in internal baccalaureate 43 said they "Always" succeed and 13 others students confirm "Never" have succeeded in internal baccalaureate.

The rate of answers that said they "sometimes" succeed in baccalaureate is high $(47,2 \%)$, this shows that these students are on the way of success because motivated, they will make more effort to success in exam. Also those that "Always" succeed will keep their speed of which is a psychologic advantage for them. For those that "Never" succeed they will lack of motivation, that's why the teachers that are conscious for improvement of their students should proceed by the diagnostic of mistakes then move to remediation during the school year.

Globally, we can say that students in their majority (modalities "Always" and "sometimes") succeed in internal baccalaureate exam seen to by similar to the external baccalaureate but are not the same. This illusion of having succeeded in internal baccalaureate sign of assurance made many students failed in external baccalaureate. After presenting and analysing the data, the task consists now to interpret them, which means to proceed to a reading of results to find to out the sense of singularity. Otherwise the interpretation of results makes intelligible and understandable the data in light of the problem. At the end of this activity, we have confronted the results to these of hypothesis or not. One of the questions of beginning is to explore the impact of educational 
practices and technics of teachers of terminal class in science

It came out from the results of inquiries on the presentation of teachers that teachers check " sometimes" the previous knowledge (25) some "Never" do it (23). The majority of teachers make effort to awakening the curiosity of their students before starting the lesson of the day (28).

These two first steps are crucial in the process of the transmission of knowledge. In fact the checking of previous knowledge allows the teachers to make the point on the previous knowledge very important for the following learning: the reinforcement or the remediation. The educational reinforcement consist to clarify more on the well known courses by the students in view to consolidate, while the remediation consists of explaning again the course that not been well understood or not at all by the students so that they may get in well . unfortunately, many of teachers do not incite the interest of students for their courses.

In fact, the sensibilisation of students for the adhesion to the course is essential for the participation of students to this activity.

The activity of teaching should have and interest an utility for the students, it's important that the teachers attracts the attention of the students on this point from the beginning. It is important to take time to introduce the topic by an anecdote, an extract of film, to place the students in front of problem, to realize a plan of the course to teach".

The teacher in his attitude should let appear "passion or (...) a great interest for the subject that he has the mission to transmit". DESCHUYTENEER Marlène (2010:28) or many exercise the work not by calling but simply by necessity. The students do not see in them the "passionnates", the "lovers" of this subject. During the period of teaching sequencies we have note that many teachers (63) have privileged the interaction between them and the students. This, shows clearly that the majority of teachers use the interactive method. For COCHE et al., (2006:16) in the setting at work of active methods, the teacher activity is "shared between the regulation of the activity and the behavior of students from one side and the learning and the development of students and the other side. In fact, the active method put the children in the center of his learn- ing. The student is the main actor of his learning and for this, he has to participate actively to the process of acquisition of knowledge by his intervention in the class during the frequencies of the courses, of applied assignments individually or collectively, the resolution of exercises and the demonstrations. For this, the teacher should watch over and organise the students in group of work by one side, to allow them for mutual in the research of knowledge on the other side, to encourage them for more mutual opening. For DESCHUYTENEER Marlène (2010: 22) the teacher should organize the work in group in form "of reflexions and exchanges on a certain topic, followed by a predefined objective (in this context) a taking of responsibility is possible for each of the members that make and allowed the confrontation of ideas. "We have noted that the majority of teachers are doing it looking at the score "sometimes" (59) and "Always" (49). But the low results in Baccalaureat these last years call on the teachers to make more effort in the educational practices even to contextualize them because the teaching practice recall Altet (2002), it is not only the seen acts, actions, reactions but this is compose of the procedures of setting at work of the activity in a situation given by somebody, the choices taken of decisions. BOU (2002) speak, to this talk, some procedures of contextualization of the practice. In the process of transmission and acquisition of knowledge, the expression plays a very central role.

The speech in the class has been always considered as an efficient tool for teaching. If this allows the teacher to transmit the knowledge to explain and to explore ideas, it also allows the student to express what he concived what he kept from the teaching and to exchange with others. "The speech constitute a vital mediation between the cognitive spaces and cultural between the teacher and the learner, between the society and the individu, between what the child knows and understands already and what remains for him to know and understand". Robin Alexander (2009). We asked ourselves if exchanges in class is profitable for students. In fact, the rate of failure in exam and the several lacks (gaps) in oral expression noticed from many students of terminal classes show that exchanges between student-student and between student and teacher aren't of constructive nature from one side, for the acquisition of skills and the knowledge at 
the other side for the externalization of students thought. In fact, most of the students by fear or by complex refuse to express or to speak in front of the teacher and their colleagues in the class. This situation of withdraw into oneself hinder the possibilities of adjustement and the remediation of bad conceptions and of bad learnings.

During the situation of learning, the good teacher is the one that make all the students to participate to his subject, increase conversation and exchanges in the class. The teacher that try to participate the whole class controls constantly by looking at the participation of his students.

He's attentive to the one participation of some students and call them from his voice or eyes. He doesn't only be contented with the actives ones, the more quick or the more interested. He takes some precautions to avoid that a student doesn't feel more or less exclue.

This fundamental attitude lack cruelly with the teachers of the secondary schools in the region of Mayo-Kebbi East. They are contented of brilliant students that participate actively to their courses and let others.

Also, they lack to inform the parents of the difficulties that their children, face in the class, which is essential. The conversation has the objective of mutual information the research of exchange and a better understanding from one to another based on respect and trust. School and the family are complementary and should engage themselves in a form of collaboration or the success of the student. The teacher should privilege this dialog way to search the means of progress of the student, that each in his own domain can contribute. It seens that this dialog is inexistant in the secondary schools of the region, and this for lack of knowledge and availability of the teachers. In fact, many of teachers aren't professional don't know that they have other charges out of their teachings in the classes. The education of a child is all: he understands the school activities and those out of school (extra-school activities)

\section{Conclusion}

The present study well targeted the regulation of learning as factors that determine the results of Baccalaureat in Science in the secondary schools of Mayo-Kebbi East.
The question of the beginning: the regulation of learning does it influence the results of Baccalaureat in Science? The partial answer to this question is certainly: the regulation of learning influence the results of Baccalaureat in science. The general objective of study is to appreciate the link that exists between the regulation of learnings and the results of Baccalaureat in Science. To this, an inquiry has been done on 106 students of Terminal class that repeat their classes in the region of Mayo-Kebbi East using a questionnaire. Collected data have been analysed by the simple linear regression.

The results of the inquiry have shown that the majority of teachers of Mayo-Kebbi East have set in application the active education that the student is the main actor of his learning (previous knowledge; life history; lesson of the days, explanation, announcement on the next sequence). The results of Baccalaureat are low because the teachers are not contractualised. Beyond the simple course taught in class the good teacher should take note of the factors of environment that can interfere in learning and the school success of the student (family, economic, social, politic).

\section{REFERENCES}

ALTEM, "Research approach on the learning practice plural analysis" French review of Education $n^{\circ} 138,2002$

BRU M., "Teaching practices: Researches to confront and to develop" French review of Education n`138, 2002, pp. 63-73

COCHE F. and al. (2006). Educational practices of primary school success of students from disadvantage background. Free University of Bruxelles: Science Education Service.

DESCHUYTENEER Marlène (2010). Active Education or how to create the motivation of students. End of study work presented in view of the obtention of Educational Aptitude certificate. Teaching Institute of Social Promotion of French Community of Morlanwelz

Rubin Alexander (2009). For usage of the speech in class. International comparison. International Review of Education of Sèvres, Avril 2009, $n^{\circ} 150$

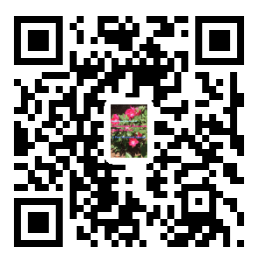

